\title{
Sinulariolide suppresses LPS-induced phenotypic and functional maturation of dendritic cells
}

\author{
TING-WEN CHUNG ${ }^{1 *}$, YI-RONG LI $^{2-4 *}$, WEI YUAN HUANG ${ }^{4}$, JUI-HSIN SU ${ }^{5}$, HONG-LIN CHAN ${ }^{1}$, \\ SHENG-HAO LIN ${ }^{2-4}$, CHIN-SAN LIU ${ }^{2,6}$, SHIH-CHAO LIN ${ }^{7}$, CHI-CHIEN LIN ${ }^{4,8,9}$ and CHING-HSIUNG LIN ${ }^{2,3,10}$ \\ ${ }^{1}$ Institute of Bioinformatics and Structural Biology and Department of Medical Sciences, National Tsing Hua University, \\ Hsinchu 30013; ${ }^{2}$ Department of Medical Research; ${ }^{3}$ Department of Internal Medicine, Division of Chest Medicine, \\ Changhua Christian Hospital, Changhua 50006; ${ }^{4}$ Institute of Biomedical Science, National Chung-Hsing University, \\ Taichung 40227; ${ }^{5}$ National Museum of Marine Biology and Aquarium, Pingtung 944; ${ }^{6}$ Department of Neurology, \\ Changhua Christian Hospital, Changhua 50006; ${ }^{7}$ Institute of Genomics and Bioinformatics, National Chung-Hsing University, \\ Taichung 40227; ${ }^{8}$ Department of Health and Nutrition, Asia University, Taichung 41354; ${ }^{9}$ Department of Medical Research, \\ China Medical University Hospital, Taichung 40402; ${ }^{10}$ Department of Respiratory Care, College of Health Sciences, \\ Chang Jung Christian University, Tainan 71101, Taiwan, R.O.C.
}

Received October 7, 2016; Accepted June 6, 2017

DOI: $10.3892 / \mathrm{mmr} .2017 .7480$

\begin{abstract}
The dendritic cell (DC) maturation process is essential for the development of $\mathrm{T}$ cell responses and immune tolerance. Accordingly, DCs are considered a major target in the development of immunomodulating agents. In the present study, the effect of sinulariolide, an active compound isolated from the cultured soft coral Sinularia flexibilis, on lipopolysaccharide (LPS)-induced murine bone marrow-derived DCs was evaluated. The different phenotypes, cytokine secretion and the mix-lymphocyte reaction of DCs were detected using flow cytometry and ELISA. The experimental results revealed that the phenotypic and functional maturation of DCs stimulated by LPS were markedly reduced by sinulariolide in a concentration-dependent manner, including the expression of co-stimulatory molecules (CD40, CD80 and CD86). In addition, sinulariolide reduced the release of tumor necrosis factor- $\alpha$, interleukin (IL)-6, IL-12 and nitric oxide from the LPS-activated DCs, decreased their abilities to stimulate allogeneic $\mathrm{T}$ cell proliferation, and inhibited LPS-induced nuclear
\end{abstract}

Correspondence to: Professor Chi-Chien Lin, Institute of Biomedical Science, National Chung-Hsing University, 50 Kuo-Kuang Road, Taichung 40227, Taiwan, R.O.C.

E-mail: lincc@dragon.nchu.edu.tw

Dr Ching-Hsiung Lin, Department of Internal Medicine, Division of Chest Medicine, Changhua Christian Hospital, 135 Nanhsiao Street, Changhua 50006, Taiwan, R.O.C.

E-mail: 47822@cch.org.tw

*Contributed equally

Key words: dendritic cell, maturation, sinulariolide, soft coral, c-Jun $\mathrm{N}$-terminal kinase, nuclear factor- $\mathrm{\kappa} \mathrm{B}$ factor- $\kappa \mathrm{B}$ pathways. These findings offer novel insight into the immunopharmacological function of sinulariolide and its effects on DCs.

\section{Introduction}

Dendritic cells (DCs) are bone marrow-derived professional antigen-presenting cells, which are critical in the regulation of adaptive immune responses. Immature DCs usually reside in peripheral tissues, expressing low levels of co-stimulatory molecules (CD80, CD86 and CD40), which disable them from activating naïve T cells. Immature DCs begin maturation following uptake of antigens and exposure to microbial agents or inflammatory mediators in peripheral tissues $(1,2)$. The common characteristics of DC maturation include the upregulation of co-stimulatory molecules and major histocompatibility complex (MHC) class II on the cell surface, reduced capacity for antigen uptake, production of various inflammatory cytokines, and trafficking to secondary lymphoid organs through afferent lymphatic vessels. Subsequently, DCs present antigenic peptides and stimulate naïve antigen-specific $\mathrm{T}$ cells in lymphoid organs (3). Overall, the DCs are a feasible therapeutic target for the pharmacological modulation of immune responses, and the inhibition of DC maturation represents a strategy for modulating immune responses (4).

Natural compounds derived from marine organisms serve as potentially valuable sources for the identification of immunomodulatory drugs for application in the biotechnology and pharmaceutical industries. Cembrane diterpenoids and their cyclized derivatives are the most abundant metabolites of soft corals and vary substantially in structural complexity (5-7). These cembranes have a defensive function in resisting natural predators, including other corals and fish, and settlement by a variety of microorganisms $(8,9)$. In addition, cembranes have been shown to possess different pharmacological activities in anti-inflammatory $(10,11)$ and antitumor effects $(12,13)$. 
Sinulariolide, a cembrane-type diterpenoids, is an active compound isolated from the cultured soft coral Sinularia flexibilis. This compound has been reported to exhibit biological activities, which include antimicrobial (14) and anticancer activities (15-18). However, its effect on normal immune function remains to be fully elucidated. In the present study, whether sinulariolide can affect the maturation and functional properties of murine bone marrow-derived dendritic cells was investigated, and their underlying signaling pathways were examined.

\section{Materials and methods}

Mice and preparation of bone marrow-derived murine DCs. Female C57BL/6 mice ( $\mathrm{n}=20$; 6-8-weeks-old; 20-25 g) were purchased from the National Laboratory Animal Center (Taipei, Taiwan). The mice were housed under a controlled temperature $\left(22 \pm 2^{\circ} \mathrm{C}\right)$ and humidity $(45-65 \%)$ with a 12 -h light/dark cycle, and free access food and water. Procedures governing the use and care of animals were performed according to the Institutional Animal Care and Use Committee guidelines and approved by the Bioethics Committee of National Chung-Hsing University (Taichung, Taiwan). The murine bone marrow-derived DCs were prepared as previously described (19).

Chemicals. Sinulariolide was isolated from the cultured soft coral Sinularia flexibilis according to previously reported procedures (20) and was provided by Dr Jui-Hsin Su (National Museum of Marine Biology and Aquarium, Pingtung, Taiwan). The stock solution was prepared at a concentration of $50 \mathrm{mg} / \mathrm{ml}$ in dimethyl sulfoxide (DMSO; Sigma Aldrich; Merck Millipore, Darmstadt, Germany). The working solution was freshly prepared by diluting with medium to desired concentrations.

Cell viability and apoptosis assay. The DCs $\left(1 \times 10^{6}\right)$ were prepared by treating with different concentrations of sinulariolide with or without $100 \mathrm{ng} / \mathrm{ml} \mathrm{LPS}$ at $37^{\circ} \mathrm{C}$ for $24 \mathrm{~h}$. Cytotoxicity was examined using a Cell Counting kit-8 (CCK-8; Dojindo Molecular Technologies, Inc., Kumamoto, Japan) according to the manufacturer's protocol. The absorbance was recorded on a microplate reader (Tecan Group Ltd., Männedorf, Switzerland) at a wavelength of $450 \mathrm{~nm}$. For the analysis of apoptosis, the cells were stained with an Annexin V kit (Invitrogen; Thermo Fisher Scientific, Inc., Waltham, MA, USA), according to the manufacturer's protocol, and determined on an Accuri 5 flow cytometer (BD Biosciences, San Jose, CA, USA). The mean fluorescence intensity was calculated using C6 Accuri system software (BD Biosciences).

Flow cytometric analysis of surface molecules. The DCs $\left(1 \times 10^{6}\right)$ were treated with DMSO $(0.1 \%)$ or sinulariolide for $1 \mathrm{~h}$ at $37^{\circ} \mathrm{C}$, followed by LPS $(100 \mathrm{ng} / \mathrm{ml})$ stimulation at $37^{\circ} \mathrm{C}$ for $24 \mathrm{~h}$. The expression of co-stimulatory markers CD40, CD80, and CD86 were detected on an Accuri 5 flow cytometer. Immunofluorescence staining for flow analysis was performed using mouse IgG anti-mouse CD11 mAb-FITC conjugated (1:100 dilution; cat. no. 553,801; BD Biosciences), mouse IgG anti-mouse CD80 mAb-phycoerythrin (PE) conjugated
(1:100 dilution; cat. no. 104,708; BioLegend, Inc., San Diego, CA, USA), mouse IgG anti-mouse CD86 mAb-PE conjugated (1:100 dilution; cat. no. 105,008; BioLegend, Inc.), mouse IgG anti-mouse CD40 mAb-PE conjugated (1:100 dilution; cat. no. 12-0401-82; eBioscience; Thermo Fisher Scientific, Inc.) for $1 \mathrm{~h}$ at $4^{\circ} \mathrm{C}$. The mean fluorescence intensity was calculated using C6 Accuri ${ }^{\mathrm{TM}}$ system software (BD Biosciences).

Cytokine and nitric oxide (NO) assay. Centrifugation was performed at $1,000 \mathrm{x}$ for $15 \mathrm{~min}$ at $4^{\circ} \mathrm{C}$, then the levels of tumor necrosis factor (TNF)- $\alpha$, interleukin (IL)- 6 and IL-12p70 in the culture supernatants were determined using murine ELISA kits for TNF- $\alpha$ (cat. no. 900-K54), IL-6 (cat. no. 900-K50), and IL-12p70 (cat. no. 900-K97; PeproTech, Inc., London, UK) according to the manufacturer's protocol. The production of $\mathrm{NO}$ was assayed indirectly by measuring the levels of nitrite $\left(\mathrm{NO}_{2}^{-}\right)$in the culture supernatants using a colorimeter assay based on the Griess reaction.

Reverse transcription-quantitative polymerase chain reaction (RT-qPCR) analysis. Total RNA isolation was performed using TRIzol (Invitrogen; Thermo Fisher Scientific, Inc.). Total RNA $(2 \mu \mathrm{g} ; 10 \mu \mathrm{l})$ was reverse transcribed using M-MLV reverse transcriptase (Promega Corporation, Madison, WI, USA) to cDNA in a $20 \mu 1$ final reaction volume containing M-MLV 5X Reaction Buffer $(5 \mu \mathrm{l}), 10 \mathrm{mM}$ dNTP $(1 \mu \mathrm{l}), 500 \mu \mathrm{g} / \mathrm{ml}$ oligo dT15 primers $(1 \mu \mathrm{l})$ and nuclease-free water $(3 \mu \mathrm{l}$; all Promega Corporation), which were incubated at $42^{\circ} \mathrm{C}$ for $15 \mathrm{~min}$. A total of $100 \mathrm{pg}$ of cDNA was used to initiate qPCR, which was performed using the SYBR-Green PCR Master Mix (Applied Biosystems; Thermo Fisher Scientific, Inc.) in the ABI 7500 Fast Real-Time system (Applied Biosystems; Thermo Fisher Scientific, Inc.). The thermocycling conditions were as follows: $95^{\circ} \mathrm{C}$ for $5 \mathrm{~min}$, followed by 40 cycles of $95^{\circ} \mathrm{C}$ for $15 \mathrm{sec}$ and $60^{\circ} \mathrm{C}$ for $1 \mathrm{~min}$. The primer pairs used were as follows: Inducible nitric oxide synthase (iNOS), forward 5'-ACATCG ACCCGTCCACAGTAT-3' and reverse 5'-CAGAGGGGT AGGCTTGTCTC-3'; GAPDH, forward 5'-CGTGTTCCTACC CCCAATGT-3' and reverse 5'-TGTCATCATACTTGGCAG GTTTCT-3'. The $2^{-\Delta \Delta \mathrm{Cq}}$ method (21) was used to normalize transcription to GAPDH and calculate the fold induction relative to controls, which were without sinulariolide treatment.

$D C$-induced mixed lymphocyte reaction. The process of determining allogeneic mixed lymphocytes was performed as described previously (22). Briefly, enriched CD4 ${ }^{+} \mathrm{T}$ cells were negatively purified from the spleen of C57BL/6 mice using a $\mathrm{CD}^{+}{ }^{+}$T-cell Isolation kit (Miltenyi Biotech, Bisley, UK). The DCs were treated with DMSO $(0.1 \%)$ or sinulariolide $(10 \mu \mathrm{M})$ in the presence or absence of LPS (100 ng/ml) for $18 \mathrm{~h}$, which was added in graded doses to $2.5 \times 10^{5}$ allogeneic $\mathrm{T}$ cells in round-bottom 96 -well plates. The plates were incubated at $37^{\circ} \mathrm{C}$ for $48 \mathrm{~h}$ and $\mathrm{T}$ cell proliferation was determined using a CCK-8 assay.

Western blot analysis. The DCs were seeded at a density of $2 \times 10^{6}$ cells per six-well plate and pretreated with DMSO $(0.1 \%)$ or sinulariolide for $1 \mathrm{~h}$, followed by stimulation with LPS $(100 \mathrm{ng} / \mathrm{ml})$ for the indicated durations. Western blot analysis was performed as described previously (22). In brief, the total 

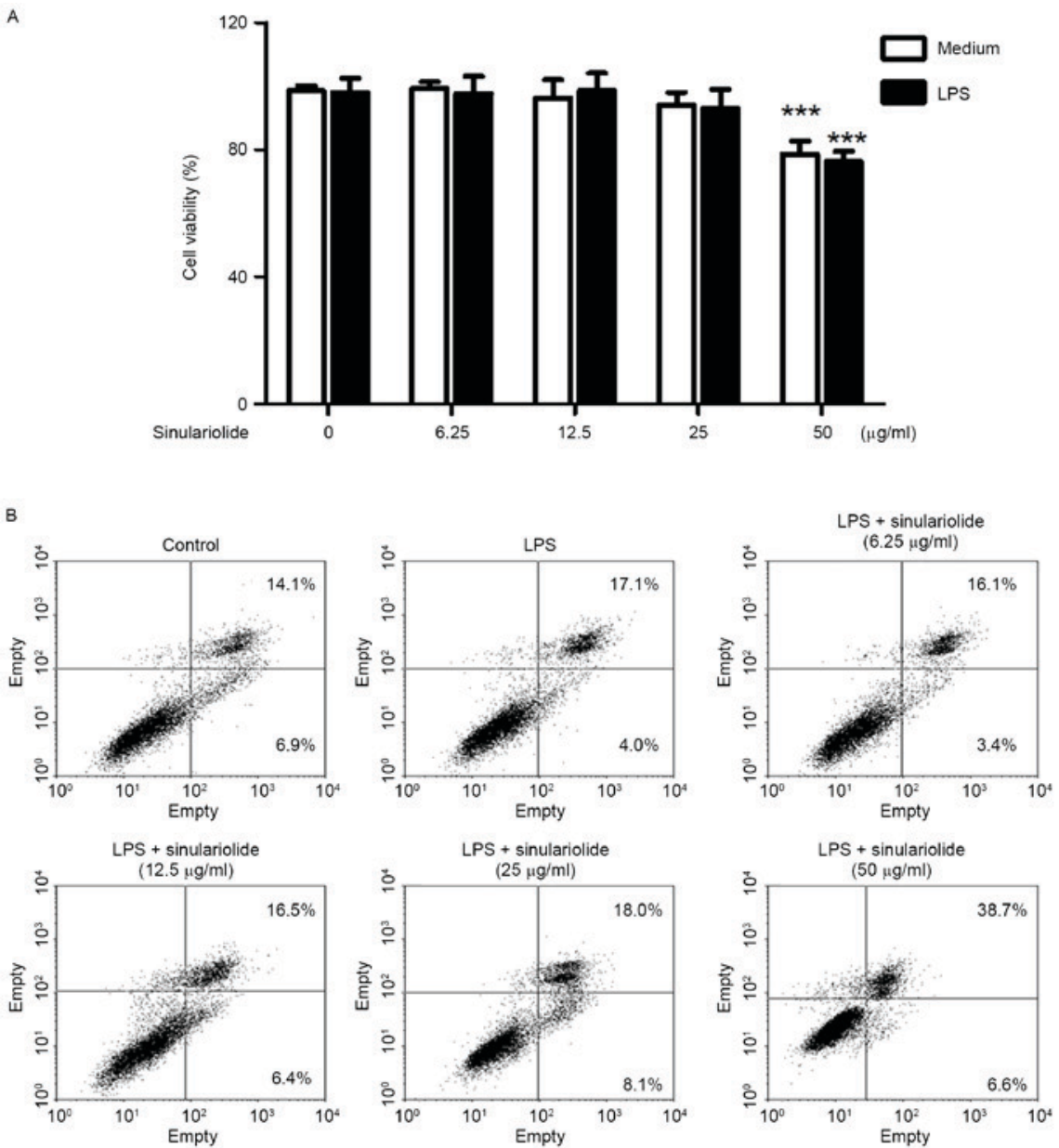

c

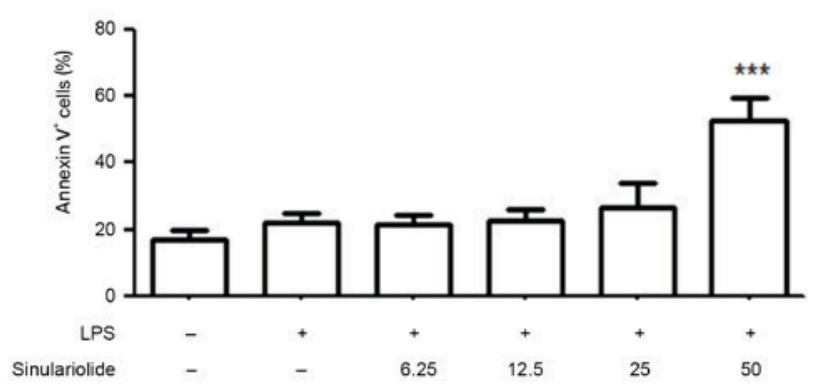

Figure 1. Sinulariolide shows no cytotoxic effect against DCs. (A) Murine bone marrow-derived DCs were treated with different doses of sinulariolide in the absence or presence of $100 \mathrm{ng} / \mathrm{ml}$ LPS for $24 \mathrm{~h}$, and then assessed using a Cell Counting kit- 8 assay. Data are expressed as the mean \pm standard deviation of triplicate values. (B) Treated cells were stained with Annexin V/PI and the Annexin $\mathrm{V}^{+}$cells were examined using flow cytometry. (C) Quantitative data are expressed as the mean \pm standard deviation of triplicate values and representative of three independent experiments with similar results. ${ }^{* * *} \mathrm{P}<0.001$ vs. dimethyl sulfoxide-treated control group. DCs, dendritic cells; LPS, lipopolysaccharide.

cell lysates were extracted in RIPA lysis and extraction buffer (Thermo Fisher Scientific, Inc.). The protein concentrations were measured using a Bio-Rad protein assay kit (Bio-Rad Laboratories, Inc., Hercules, CA USA), following which $20 \mu \mathrm{g}$ of protein was subjected to $10 \%$ SDS-PAGE and transferred onto nitrocellulose membranes. The membranes were incubated with antibodies against phosphorylated (p-)extracellular signal-regulated kinase (ERK; 1:1,000 dilution; cat. no. 4370), ERK (1:1,000 dilution; cat. no. 3192;), p-p38 (1:1,000 dilution; cat. no. 4631), p38 (1:1,000 dilution; cat. no. 8690), p-AKT (1:1,000 dilution; cat. no. 4060), AKT (1:1,000 dilution; cat.

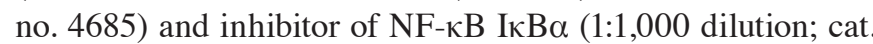
no. 4812; Cell Signaling Technology, Inc., Danvers, MA, USA) overnight at $4^{\circ} \mathrm{C}$. The membranes were then incubated with horseradish peroxidase-labeled secondary antibody $(1: 2,000$ dilution; cat. no. 111-035-003; Jackson ImmunoResearch Laboratories, Inc., West Grove, PA, USA) overnight at $4^{\circ} \mathrm{C}$. The protein-antibody complexes were detected by enhanced chemiluminescence (GE Healthcare Life Sciences, Chalfont, UK), performed using a Hansor Luminescence Image system (Hansor, Taichung, Taiwan). The blots were quantified by densitometric analysis using ImageJ software version 1.47 (National Institutes of Health, Bethesda, MD USA).

Preparation of nuclear extracts and $N F-\kappa B$ activity assay. Nuclear extracts were prepared using NE-PER Nuclear and 
Cytoplasmic Extraction reagents (Pierce; Thermo Fisher Scientific, Inc.) according to the manufacturer's protocol. The samples were stored at $-80^{\circ} \mathrm{C}$ for the analysis of $\mathrm{NF}-\kappa \mathrm{B}$ activity. The activity of $\mathrm{NF}-\kappa \mathrm{B}$ was measured in the nuclear protein extracts $(15 \mu \mathrm{g})$ using the TransAM ${ }^{\mathrm{TM}} \mathrm{NF}-\kappa \mathrm{B}$ p65 ELISA-based assay kit (Active Motif, Carlsbad, CA, USA), which is an ELISA-based method designed to detect NF- $\kappa$ B p65 subunit activation. The assay was performed according to the manufacturer's protocol and analyzed using a microplate reader at $450 \mathrm{~nm}$, with a reference wavelength of $655 \mathrm{~nm}$ (Tecan Group Ltd.).

Statistical analysis. Data are expressed as the mean \pm standard deviation of the indicated number of experiments. The statistical significance of differences between groups were examined using one way analysis of variables followed by Tukey's test or Student's t-test (GraphPad version 5 for Windows; GraphPad Software, Inc., San Diego, CA USA). $\mathrm{P}<0.05$ was considered to indicate a statistically significant difference.

\section{Results}

Sinulariolide has no significant cytotoxic or apoptotic effects on DCs. The present study first evaluated the cytotoxicity of sinulariolide on DCs by treating DCs with different concentrations of sinulariolide in the presence or absence of LPS $(100 \mathrm{ng} / \mathrm{ml})$ for $24 \mathrm{~h}$. No significant toxic effects were observed following treatment with sinulariolide in the concentration range of $6.25-25 \mu \mathrm{g} / \mathrm{ml}$, however, $50 \mu \mathrm{g} / \mathrm{ml}$ sinulariolide significantly decreased cell viability (Fig. 1A). The expression of Annexin V and CD11c ${ }^{+}$were then analyzed, in which sinulariolide $(6.25-25 \mu \mathrm{g} / \mathrm{ml})$ exerted minimal or no apoptotic effects on DCs (Fig. 1B and C). Therefore, sinulariolide concentrations $<25 \mu \mathrm{g} / \mathrm{ml}$ were used in the following experiments.

Reduction in the expression of co-stimulatory molecules by sinulariolide. As co-stimulatory molecules are markers of the maturation of DCs $(1,2)$, the present study investigated whether sinulariolide can alter the expression levels of CD40, CD80 and CD86 in LPS-treated DCs. As shown in Fig. 2, the expression levels of CD40, CD80 and CD86 were increased in immature DC following LPS treatment (100 $\mathrm{ng} / \mathrm{ml})$ for $24 \mathrm{~h}$, and sinulariolide treatment effectively decreased the induction of co-stimulatory molecules in a dose-dependent manner.

Sinulariolide inhibits the secretion of proinflammatory mediators in LPS-induced maturation. Subsequently, the present study evaluated the inhibitory effect of sinulariolide on the production of proinflammatory cytokines and NO by LPS-stimulated DCs. The levels of TNF- $\alpha$, IL-6, IL-12 and NO in the medium were measured following treatment of the immature DCs with sinulariolide for $1 \mathrm{~h}$, followed by LPS (100 $\mathrm{ng} / \mathrm{ml}$ ) stimulation for $24 \mathrm{~h}$. Despite the fact that the LPS-treated DCs showed markedly increased production of IL-12 p70, TNF- $\alpha$, IL-6 and NO, compared with the untreated DCs, the results showed that sinulariolide suppressed this LPS-induced release of cytokines and NO in a dose-dependent manner (Fig. 3A-D). The present study also measured the
mRNA levels of iNOS using RT-qPCR analysis to quantify the inhibitory effect of sinulariolide on $\mathrm{NO}$, which is regulated by iNOS. The data, as shown in Fig. 3E, revealed that sinulariolide markedly decreased the mRNA level of iNOS in the LPS-stimulated DCs (Fig. 3E).

Sinulariolide suppresses the ability of LPS-stimulated DCs to activate allogeneic $T$ cells. The effect of sinulariolide on DC-mediated allogeneic $\mathrm{T}$ cell proliferation was then examined. The LPS-stimulated DCs were pretreated with or without sinulariolide for $24 \mathrm{~h}$ and co-cultured with allogeneic spleen $\mathrm{CD}^{+}{ }^{+} \mathrm{T}$ cells for $48 \mathrm{~h}$ prior to measuring $\mathrm{T}$ cell proliferation. As shown in Fig. 4A, the DCs treated with LPS induced more marked proliferative responses in allogeneic T cells, compared with the untreated DCs, when the T/DC cell ratio was $5: 1$. This effect was reduced by sinulariolide in the dose range of $6.25-25 \mu \mathrm{g} / \mathrm{ml}$ (Fig. 4B).

Sinulariolide represses the activation of $N F-\kappa B$ in $L P S$-stimulated DCs. To further elucidate the possible suppressive molecular mechanism of sinulariolide, the present study examined and identified the signaling pathways, which may be affected by sinulariolide in the LPS-stimulated DCs. As shown in Fig. 5A, ERK, c-Jun N-terminal kinase (JNK), p38 mitogen-activated protein kinases (MAPKs) and AKT were phosphorylated in the DCs upon stimulation, and sinulariolide appeared to partially reduce the LPS-induced phosphorylation of AKT at $30 \mathrm{~min}(\mathrm{P}=0.08)$ and $60 \mathrm{~min}(\mathrm{P}=0.07)$, compared with p-ERK, p-p38 and p-JNK. The expression of non-phosphorylated proteins were not affected by sinulariolide. The present study also analyzed the protein levels of IкB and the binding activity of $N F-\kappa B$ using a Trans $A M^{\mathrm{TM}} \mathrm{NF}-\kappa \mathrm{B}$ assay. The results showed that sinulariolide decreased the degradation of $\mathrm{I} \kappa \mathrm{B}$ induced by LPS (Fig. 5B) and significantly inhibited the LPS-induced NF- $\mathrm{B}$ binding activity of p65 (Fig. 5C). This suggested that sinulariolide repressed LPS-induced DC maturation via inhibition of the $\mathrm{NF}-\kappa \mathrm{B}$ pathway, which may further explain the inhibitory effect of sinulariolide on DC activation.

\section{Discussion}

The inhibitory effects of sinulariolide on the phenotype and functional activation of DCs were investigated in the present study. Sinulariolide has been shown to exert anticancer effects in various cancer cell types. In contrast to anticancer effects, the present study is the first, to the best of our knowledge, to report that sinulariolide is an immunomodulator, which can suppress the activation of DCs. The data suggested that sinulariolide had an inhibitory effect on the modulation of harmful and undesirable immune responses.

The immunogenic phenotype of mature DCs is functionally characterized by the upregulation of co-stimulatory markers (CD40, CD80 and CD86) and surface MHC molecules $(23,24)$. These distinct molecules regulate the stimulatory capacity of DCs to activate allogeneic T cell proliferation. In the present study, sinulariolide significantly decreased the LPS-induced expression levels of CD40, CD80 and CD86 in a dose-dependent manner, indicating that DCs treated with sinulariolide were resistant to phenotypic maturation. 

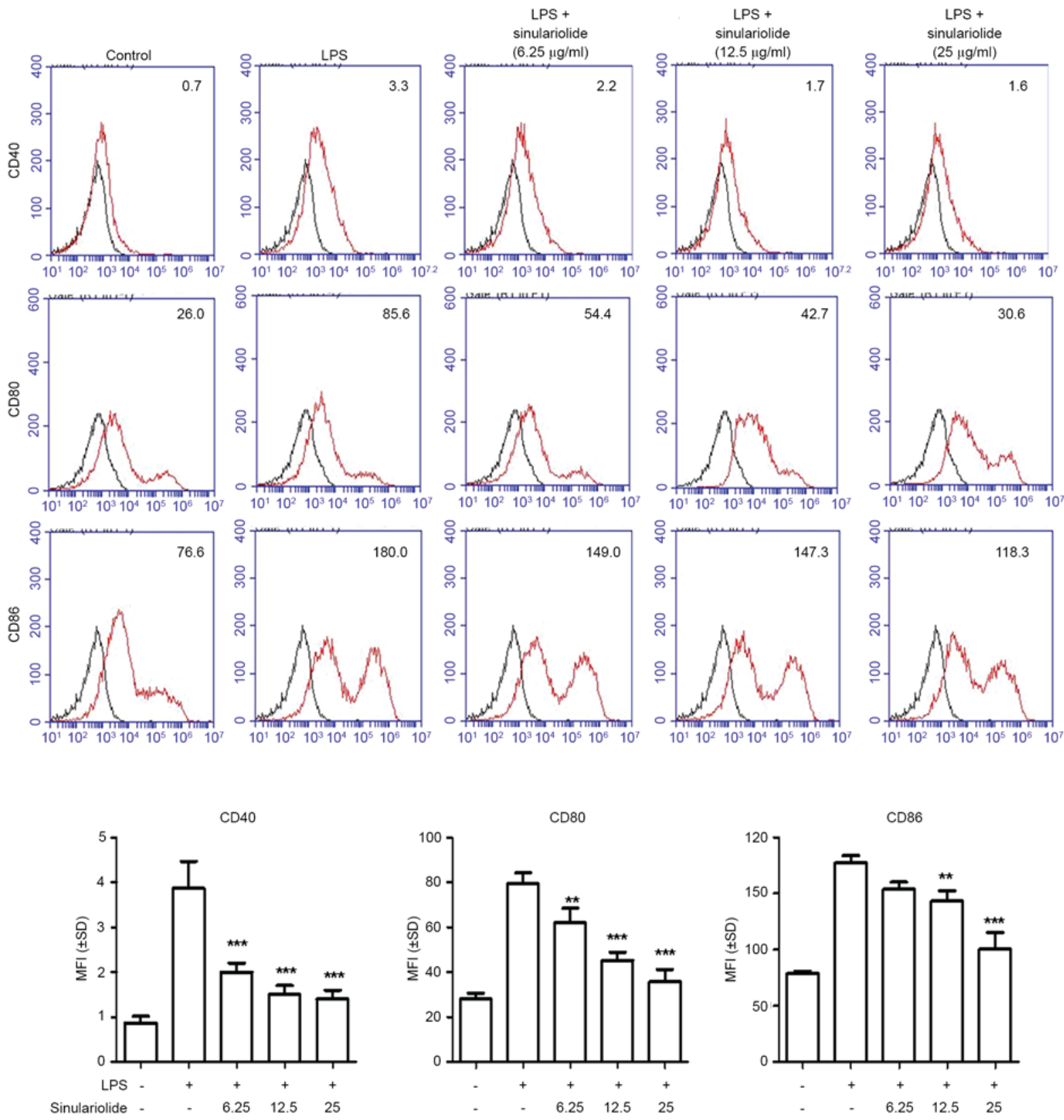

Figure 2. Sinulariolide attenuates the LPS-induced phenotypic maturation of DCs. Immature DCs were pretreated with sinulariolide for $1 \mathrm{~h}$ followed by LPS $(100 \mathrm{ng} / \mathrm{ml})$ stimulation for an additional $24 \mathrm{~h}$. Specific antibodies were used to stain cells, which were subsequently assayed using flow cytometry. The dotted line indicates the isotype antibody group. Histogram graph data show the MFI. Quantitative data are expressed as the mean \pm SD of triplicate values, and representative of three independent experiments with similar results. ${ }^{* *} \mathrm{P}<0.01$ and ${ }^{* * * *} \mathrm{P}<0.001$ vs. dimethyl sulfoxide-treated control group. DCs, dendritic cells; LPS, lipopolysaccharide; MFI, mean fluorescence intensity; SD, standard deviation.

Another distinctive feature of DC maturation is the increased production of pro-inflammatory cytokines and $\mathrm{NO}$, which have critical regulatory functions in inflammation, $\mathrm{T}$ cell differentiation and expansion. TNF- $\alpha$, IL- 6 and IL-12 are key pro-inflammatory cytokines involved in the pathogenesis of chronic inflammatory diseases. DC maturation induced by TNF- $\alpha$ augments Th1 cell differentiation, whereas IL-6 induces the differentiation of Th2 cells (25). The production of IL-12 by mature DCs is important in priming naïve $\mathrm{CD} 4^{+} \mathrm{T}$ cells to undergo Th1 differentiation (26). NO, synthesized by the enzyme NOS from L-arginine, is a potent signaling molecule, which is crucial in various physiological and pathophysiological processes (27). NO is also produced by DCs upon activation, thus providing a negative feedback mechanism to suppress lymphocyte proliferation and induce apoptosis of DCs $(28,29)$. As a result, inhibiting the production of NO with the NOS inhibitor, $\mathrm{N}^{\mathrm{G}}$-monomethyl arginine, can reduce this apoptotic process (28). Furthermore, iNOS is activated by bacterial infection and various immunogenic stimuli, including LPS, interferon- $\gamma$ or TNF- $\alpha$, enabling the generation of NO from DCs to regulate DC responsiveness in an autoregulatory feedback loop. The results of the present study showed that LPS significantly increased the expression of TNF- $\alpha$, IL- 6 and IL-12, and the release of NO/iNOS by DCs, and this increase was inhibited by sinulariolide, indicating the immunomodulatory role of sinulariolide in DC functions. 


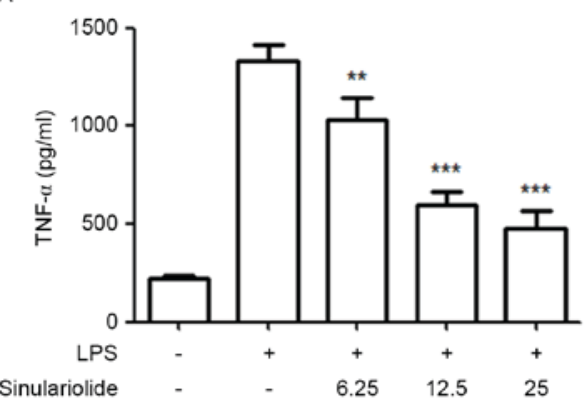

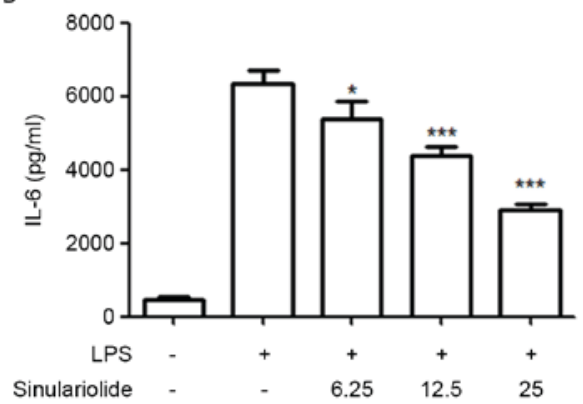

D

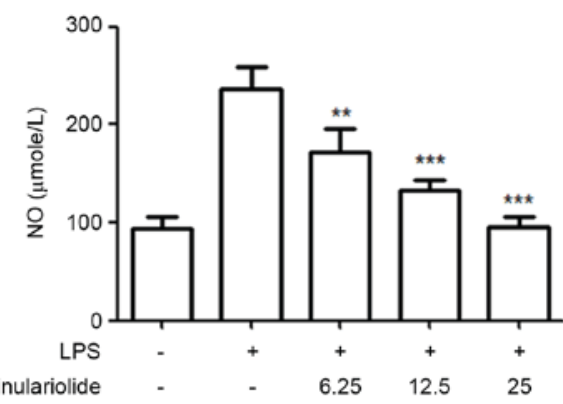

E

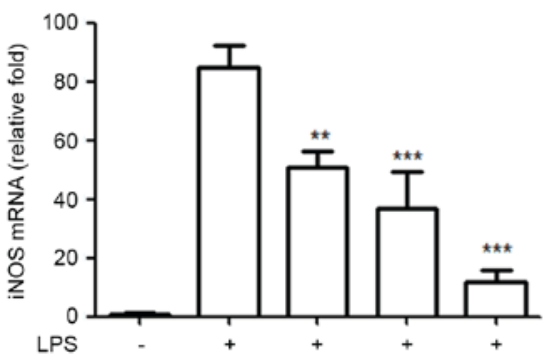

Figure 3. Sinulariolide suppresses the release of IL-12p70, TNF- $\alpha$, IL-6 and NO in LPS-stimulated DCs. Immature DCs were treated with sinulariolide for $1 \mathrm{~h}$ and then stimulated with LPS (100 ng/ml) for an additional $24 \mathrm{~h}$. Cytokine levels of (A) TNF- $\alpha$, (B) IL-6 and (C) IL-12 p70 in the culture supernatant were measured using ELISA. (D) NO was measured using Griess reagent. Data are expressed as the mean \pm standard deviation of triplicate values. (E) mRNA expression levels of iNOS were assessed using reverse transcription-quantitative polymerase chain reaction analysis using the $2^{-\Delta \Delta C q}$ method with GAPDH mRNA as a reference. Quantitative data are expressed as the mean \pm standard deviation of triplicate values. All data are representative of three independent experiments with similar results. ${ }^{*} \mathrm{P}<0.05,{ }^{* *} \mathrm{P}<0.01$ and ${ }^{* * * *} \mathrm{P}<0.001$ vs. dimethyl sulfoxide-treated control group. DCs, dendritic cells; LPS, lipopolysaccharide; TNF- $\alpha$, tumor necrosis factor- $\alpha$; IL-, interleukin; NO, nitric oxide; iNOS, inducible nitric oxide synthase.
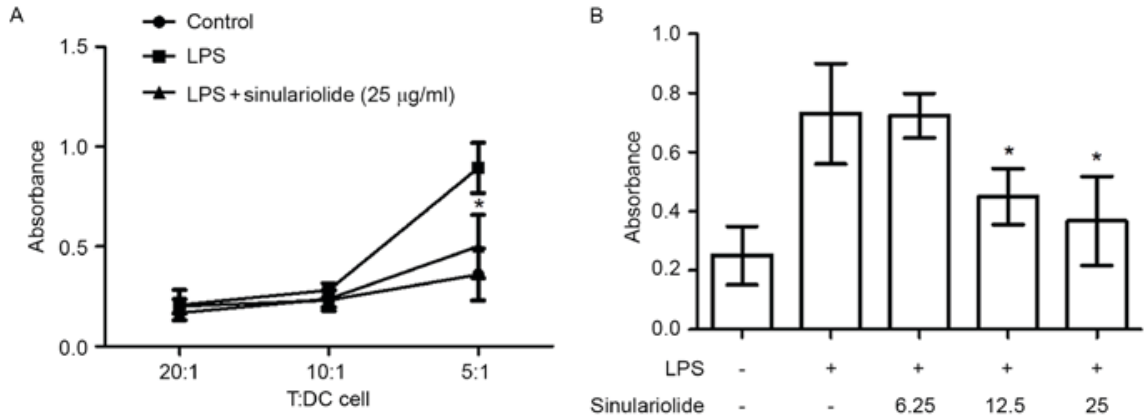

Figure 4. Sinulariolide inhibits the proliferative response of allogeneic T cells induced by LPS-stimulated DCs. Sinulariolide was used to treat immature DCs for $1 \mathrm{~h}$ and then stimulated with LPS (100 ng/ml) for an additional $24 \mathrm{~h}$. (A) Allogeneic mixed lymphocyte reaction was performed for $48 \mathrm{~h}$ using allogeneic spleen $\mathrm{CD} 4^{+} \mathrm{T}$ cells as responder $\mathrm{T}$ cells with the indicated ratios of T/DC cells. (B) Allogeneic mixed lymphocyte reaction was performed with a T/DC cell ratio of 5:1. Data are expressed as the mean \pm standard deviation of triplicate values. All data are representative of three independent experiments with similar results. ${ }^{*}<<0.05$ vs. dimethyl sulfoxide-treated control group. DCs, dendritic cells; LPS, lipopolysaccharide.

As the MAPK, phosphoinositide-3 kinase/Akt and NF- $\mathrm{BB}$ signaling pathways in DCs can be activated by LPS stimulation, it has been revealed that these signaling pathways are distinct, but overlapping, in the phenotypic maturation, 
A
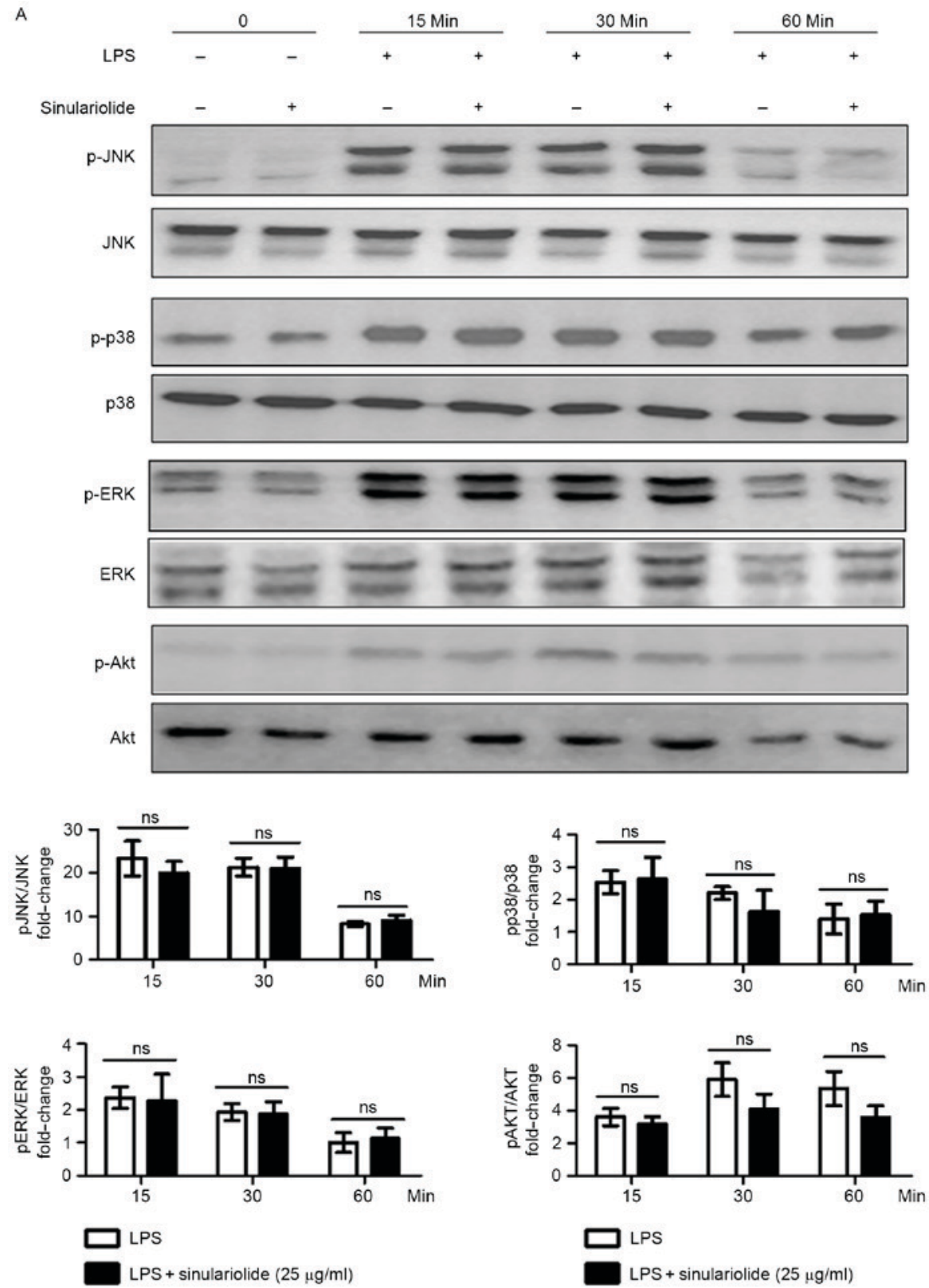

B
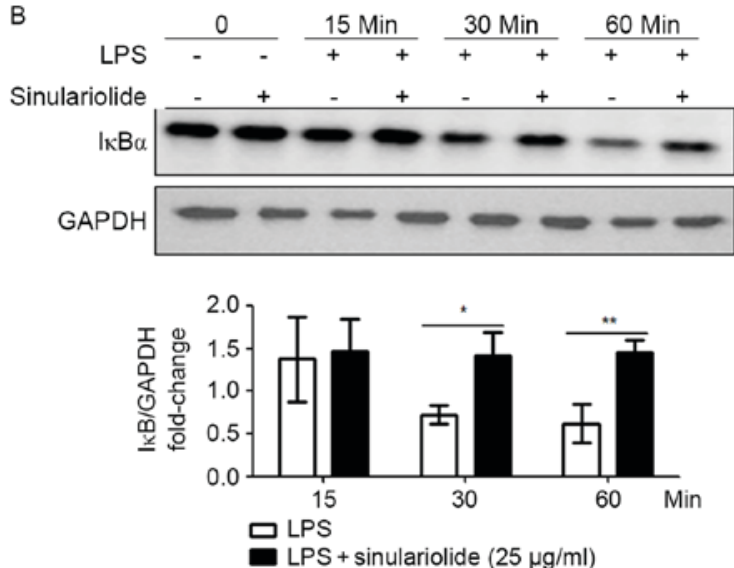

C

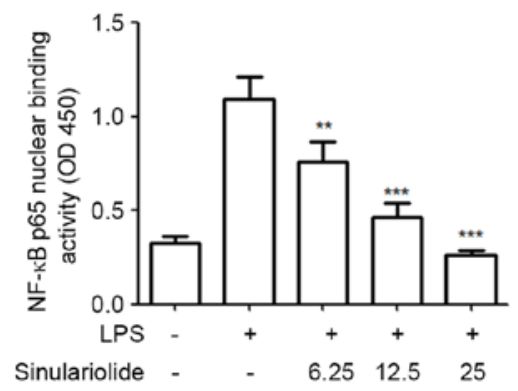

Figure 5. Inhibition of LPS-induced NF- $\mathrm{BB}$ signaling pathway in DCs by sinulariolide. Sinulariolide was used to treat immature DCs for $1 \mathrm{~h}$, stimulated with LPS $(100 \mathrm{ng} / \mathrm{ml})$ for the indicated durations and lysed for protein extraction. Levels of (A) ERK, JNK, p38 MPAK, AKT (phosphorylated and non-phosphorylated) and (B) IкB were examined by western blot assay. GAPDH was used as a loading control. Densitometric analysis was performed using Image J software. (C) NF-kB p65 DNA binding activity in nuclear extracts of DCs was determined using the TransAM kit. Data are expressed as the mean OD450 values of triplicate values. All data presented are representative of three independent experiments with similar results. ${ }^{*} \mathrm{P}<0.05,{ }^{* * *} \mathrm{P}<0.01$ and ${ }^{* * * *} \mathrm{P}<0.001 \mathrm{vs}$. dimethyl sulfoxide-treated control group. DCs, dendritic cells; LPS, lipopolysaccharide; JNK, c-Jun N-terminal kinase; ERK, extracellular signal-regulated kinase;

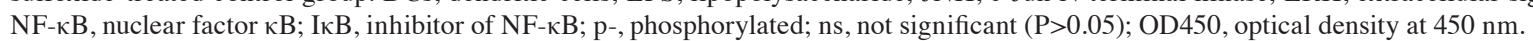


cytokine production and functional activation of DCs. Among these pathways, NF- $\kappa \mathrm{B}$ has a more important role, compared with that of JNK, in mediating LPS-stimulated DC phenotypic maturation $(30,31)$. The differentiation of human monocytes into immature DCs has been determined by the activation of p38 MAPK (32). ERK and PI3 kinase/Akt are essential in LPS-stimulated DC survival (33). In the present study, it was observed that activation of the MAPK (ERK, p38 and JNK), AKT and NF- $\mathrm{B}$ pathways were affected by LPS treatment, which was consistent with previous studies. However, pretreatment with sinulariolide exerted marked inhibitory effects on the degradation of $\mathrm{I} \kappa \mathrm{B}$ and activation of $\mathrm{NF}-\kappa \mathrm{B}$ in response to LPS stimuli, without inhibiting the LPS-induced phosphorylation of MAPK and AKT. These data suggested that the attenuation of LPS-stimulated maturation and inflammatory responses of DCs by sinulariolide were associated with downregulation of the NF- $\kappa \mathrm{B}$ signaling pathway. However, the exact mechanisms underlying the suppressive effect of sinulariolide on LPS-stimulated DC activation requires further investigation.

Previous studies have shown that the bioactivity of sinulariolide can be enhanced by conjugating hyaluronan nanoparticles (34) and that hyaluronan nanoparticle/sinulariolide aggregates exert more potent anticancer effects on lung cancer cells, compared with sinulariolide alone. Conceivably, these techniques are likely to further facilitate the development of clinical applications of sinulariolide.

In conclusion, the results of the present study demonstrated that sinulariolide suppressed LPS-stimulated DC phenotypic maturation, cytokine and NO production, and co-stimulatory molecule expression. Therefore, sinulariolide may be utilized in the treatment of autoimmune and inflammatory disorders. These findings provide novel insight into the immunopharmacological functions of sinulariolide.

\section{Acknowledgements}

The present study was supported by Changhua Christian Hospital (grant nos. 103-CCH-IRP-003 and 103-CCH-ICO-001).

\section{References}

1. Li X, He X, Liu B, Xu L, Lu C, Zhao H, Niu X, Chen S and $\mathrm{Lu}$ A: Maturation of murine bone marrow-derived dendritic cells induced by Radix Glycyrrhizae polysaccharide. Molecules 17: 6557-6568, 2012.

2. Kim GY, Lee MY, Lee HJ, Moon DO, Lee CM, Jin CY, Choi YH, Jeong YK, Chung KT, Lee JY, et al: Effect of water-soluble proteoglycan isolated from Agaricus blazei on the maturation of murine bone marrow-derived dendritic cells. Int Immunopharmacol 5: 1523-1532, 2005.

3. English K, Barry FP and Mahon BP: Murine mesenchymal stem cells suppress dendritic cell migration, maturation and antigen presentation. Immunol Lett 115: 50-58, 2008.

4. Hackstein H and Thomson AW: Dendritic cells: Emerging pharmacological targets of immunosuppressive drugs. Nat Rev Immunol 4: 24-34, 2004.

5. Li G, Zhang Y, Deng Z, van Ofwegen L, Proksch P and Lin W: Cytotoxic cembranoid diterpenes from a soft coral Sinularia gibberosa. J Nat Prod 68: 649-652, 2005.

6. Yang B, Zhou XF, Lin XP, Liu J, Peng Y, Yang XW and Liu YH: Cembrane diterpenes chemistry and biological properties. Curr Org Chem 16: 1512-1539, 2012.

7. Chao $\mathrm{CH}$, Chou KJ, Huang CY, Wen $\mathrm{ZH}$, Hsu CH, Wu YC, Dai CF and Sheu JH: Bioactive cembranoids from the soft coral Sinularia crassa. Mar Drugs 9: 1955-1968, 2011.
8. Li Y, Gao AH, Huang H, Li J, Mollo E, Gavagnin M, Cimino G, $\mathrm{Gu}$ YC and Guo YW: Diterpenoids from the hainan soft coral sinularia parva. Helvetica Chim Acta 92: 1341-1348, 2009.

9. Coll JC, Price IR, Konig GM and Bowden BF: Algal overgrowth of alcyonacean soft corals. Mar Biol 96: 129-135, 1987.

10. Lu Y, Huang CY, Lin YF, Wen ZH, Su JH, Kuo YH, Chiang MY and Sheu JH: Anti-inflammatory cembranoids from the soft corals Sinularia querciformis and Sinularia granosa. J Nat Prod 71: 1754-1759, 2008.

11. Lu Y, Su JH, Huang CY, Liu YC, Kuo YH, Wen ZH, Hsu CH and Sheu JH: Cembranoids from the soft corals Sinularia granosa and Sinularia querciformis. Chem Pharm Bull (Tokyo) 58: 464-466, 2010

12. Liu CI, Chen CC, Chen JC, Su JH, Huang HH, Chen JY and Wu YJ: Proteomic analysis of anti-tumor effects of 11-dehydrosinulariolide on CAL-27 cells. Mar Drugs 9: 1254-1272, 2011.

13. Lin YS, Chen CH, Liaw CC, Chen YC, Kuo YH and Shen YC: Cembrane diterpenoids from the Taiwanese soft coral Sinularia flexibilis. Tetrahedron 65: 9157-9164, 2009.

14. Aceret TL, Coll JC, Uchio Y and Sammarco PW: Antimicrobial activity of the diterpenes flexibilide and sinulariolide derived from Sinularia flexibilis Quoy and Gaimard 1833 (Coelenterata: Alcyonacea, Octocorallia). Comp Biochem Physiol C Pharmacol Toxicol Endocrinol 120: 121-126, 1998.

15. Wu YJ, Neoh CA, Tsao CY, Su JH and Li HH: Sinulariolide suppresses human hepatocellular carcinoma cell migration and invasion by inhibiting matrix metalloproteinase-2/-9 through MAPKs and PI3K/Akt signaling pathways. Int J Mol Sci 16: 16469-16482, 2015.

16. Chen YJ, Su JH, Tsao CY, Hung CT, Chao HH, Lin JJ, Liao MH, Yang ZY, Huang HH, Tsai FJ, et al: Sinulariolide induced hepatocellular carcinoma apoptosis through activation of mitochondrial-related apoptotic and PERK/eIF2 $\alpha / \mathrm{ATF} 4 / \mathrm{CHOP}$ pathway. Molecules 18: 10146-10161, 2013.

17. Li HH, Su JH, Chiu CC, Lin JJ, Yang ZY, Hwang WI, Chen YK, Lo $\mathrm{YH}$ and $\mathrm{Wu} \mathrm{YJ}$ : Proteomic investigation of the sinulariolide-treated melanoma cells A375: Effects on the cell apoptosis through mitochondrial-related pathway and activation of caspase cascade. Mar Drugs 11: 2625-2642, 2013.

18. Neoh CA, Wang RY, Din ZH, Su JH, Chen YK, Tsai FJ, Weng SH and Wu YJ: Induction of apoptosis by sinulariolide from soft coral through mitochondrial-related and p38MAPK pathways on human bladder carcinoma cells. Mar Drugs 10: 2893-2911, 2012.

19. Li S, Lin YC, Ho CT, Lin PY, Suzawa M, Wang HC, Chu CL, Chen DY and Lin CC: Formulated extract from multiple citrus peels impairs dendritic cell functions and attenuates allergic contact hypersensitivity. Int Immunopharmacol 20: 12-23, 2014.

20. Hsieh PW, Chang FR, McPhail AT, Lee KH and Wu YC: New cembranolide analogues from the formosan soft coral Sinularia flexibilis and their cytotoxicity. Nat Prod Res 17: 409-418, 2003.

21. Livak KJ and Schmittgen TD: Analysis of relative gene expression data using real-time quantitative PCR and the 2(-Delta Delta C(T)) method. Methods 25: 402-408, 2001.

22. Lin CC, Chu CL, Ng CS, Lin CY, Chen DY, Pan IH and Huang KJ: Immunomodulation of phloretin by impairing dendritic cell activation and function. Food Funct 5: 997-1006, 2014.

23. Caux C, Massacrier C, Vanbervliet B, Dubois B, Van Kooten C, Durand I and Banchereau J: Activation of human dendritic cells through CD40 cross-linking. J Exp Med 180: 1263-1272, 1994.

24. Pinchuk LM, Polacino PS, Agy MB, Klaus SJ and Clark EA: The role of CD40 and CD80 accessory cell molecules in dendritic cell-dependent HIV-1 infection. Immunity 1: 317-325, 1994.

25. Diehl S and Rincón M: The two faces of IL-6 on Th1/Th2 differentiation. Mol Immunol 39: 531-536, 2002.

26. Heufler C, Koch F, Stanzl U, Topar G, Wysocka M, Trinchieri G, Enk A, Steinman RM, Romani N and Schuler G: Interleukin-12 is produced by dendritic cells and mediates T helper 1 development as well as interferon-gamma production by Thelper 1 cells. Eur J Immunol 26: 659-668, 1996.

27. Moncada S, Palmer RM and Higgs EA: Nitric oxide: Physiology, pathophysiology, and pharmacology. Pharmacol Rev 43: 109-142, 1991.

28. Bonham CA, Lu L, Li Y, Hoffman RA, Simmons RL and Thomson AW: Nitric oxide production by mouse bone marrow-derived dendritic cells: Implications for the regulation of allogeneic T cell responses. Transplantation 62: 1871-1877, 1996. 
29. Lu L, Bonham CA, Chambers FG, Watkins SC, Hoffman RA, Simmons RL and Thomson AW: Induction of nitric oxide synthase in mouse dendritic cells by IFN-gamma, endotoxin, and interaction with allogenic T cells: Nitric oxide production is associated with dendritic cell apoptosis. J Immunol 157: 3577-3586, 1996

30. Neves BM, Cruz MT, Francisco V, Garcia-Rodriguez C, Silvestre R, Cordeiro-da-Silva A, Dinis AM, Batista MT, Duarte CB and Lopes MC: Differential roles of PI3-kinase, MAPKs and NF-kappaB on the manipulation of dendritic cell $\mathrm{T}(\mathrm{h}) 1 / \mathrm{T}(\mathrm{h}) 2$ cytokine/chemokine polarizing profile. Mol Immunol 46: 2481-2492, 2009.

31. Rescigno M, Martino M, Sutherland CL, Gold MR and Ricciardi-Castagnoli P: Dendritic cell survival and maturation are regulated by different signaling pathways. J Exp Med 188: 2175-2180, 1998

32. Ardeshna KM, Pizzey AR, Devereux S and Khwaja A: The PI3 kinase, p38 SAP kinase, and NF-kappaB signal transduction pathways are involved in the survival and maturation of lipopolysaccharide-stimulated human monocyte-derived dendritic cells Blood 96: 1039-1046, 2000.
33. Xie J, Qian J, Yang J, Wang S, Freeman ME III and Yi Q: Critical roles of Raf/MEK/ERK and PI3K/AKT signaling and inactivation of p38 MAP kinase in the differentiation and survival of monocyte-derived immature dendritic cells. Exp Hematol 33: 564-572, 2005.

34. Hsiao KY, Wu YJ, Liu ZN, Chuang CW, Huang HH and Kuo SM: Anticancer effects of sinulariolide-conjugated hyaluronan nanoparticles on lung adenocarcinoma cells. Molecules 21: 297, 2016. 